\title{
A case of idiopathic nephrotic syndrome treated with the homeopathic therapeutic
}

\author{
Luiz Figueira Pinto
}

Federal Rural University of Rio de Janeiro, RJ, Brazil

\begin{abstract}
Nephrotic syndrome is a chronic clinical condition and drugs used in its treatment may result in severe side-effects. Renal transplantation or renal ablation and subsequent chronic dialysis treatment may be the only feasible way to patients. The present article reports the case of a 23years-old white woman that presented nephrotic syndrome and was successfully treated with homeopathic medicines. Six kind of homeopathic diagnoses were made to build the clinical homeopathic picture of the patient and to determine the appropriate medicines, according to the clinical protocol used. Apis mellifica was the main medicine used to treat the diathesis sycosis. The satisfactory treatment outcome shows that the judicious homeopathic therapeutic may be a valuable resource in the treatment of nephrotic syndrome.
\end{abstract}

Keywords: Nephrotic syndrome; Clinical protocol; Diathesis; Sycosis; Homeopathy

\section{Introduction}

Nephrotic syndrome is a chronic clinical condition characterized by proteinuria, hypoalbuminemia, edema, and hypercholesterolemia. Edema is the predominant feature, and in time it becomes generalized and may be associated with the increase in weight, development of ascitic or pleural effusion, and decline in urine output. It is more common in children than in adults [1,2].

Drugs used in the treatment of nephrotic syndrome include corticosteroids, immunomodulators, immunosuppressant, diuretics and antibiotics. The response to these drugs depends on the cause of nephrotic syndrome. These treatments may result in severe side-effects, and there are some contraindications for their use $[1,2$, 3]. Renal transplantation or renal ablation and subsequent chronic dialysis treatment may be the only feasible way to help patients that showed resistance to the other treatments [4].

Complementary and alternative therapies are increasingly been used in a variety of clinical conditions with successful results $[5,6]$.

The present article reports the case of a 23-yearsold white woman that presented nephrotic syndrome and was successfully treated with homeopathic medicines.

\section{Case report}

The disease process started 29 months before the first homeopathic attendance, with swelling of the feet that evolved into ascites. Spontaneous remission had occurred previously on two occasions,. On that time, the idiopathic nephrotic syndrome was diagnosed after biopsy (performed at University Hospital Clementino Fraga Filho, Federal University of Rio de Janeiro) and the treatment was initiated in February 2003 and finished in August 2004, including Prednisone (20mg/day), Furosemide (40mg/day), Hidroclorotiazide (25mg/day), Simvastatin (20mg/day), Cyclophosphamide (50mg/day), Captopril (12,5mg/ day), Levofloxacin (500mg/day), Levamisole hydrochloride and Vitamin A and D, at different times., without clinical response. After a few months, renal transplantation was recommended and the patient was left without further treatment waiting for a compatible donor. In the meanwhile, she sought several complementary and alternative therapies, including orthomolecular medicine, blood-group diet and homeopathy, all equally unsuccessful. This treatment was realized in another service and occurred from October 2004 to April 2005. The patient presented with failure labor since October 2003 and received a disability retirement in January 2005. 
The first homeopathic attendance was in June 2005 , the patient presented severe swelling in the legs and ascites. She was overweight and her urine was foamy. She was prostrated and would only leave the bed or couch to go to the bathroom. (Figure 1) At that time, she was not taking any medicine. Her mother brought her to the attendance compulsorily and she was irritated, frightened and discouraged and did not bring the results of the laboratory tests. She was very frustrated and disappointed, and appeared to refuse to remember her clinical history. Her mother told me she had proteinuria, hypoalbuminemia and hypercholesterolemia.

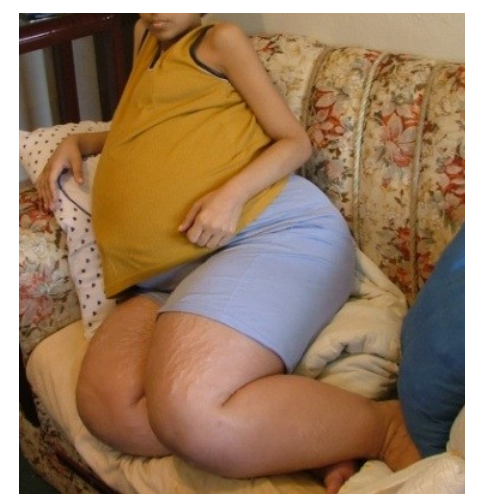

Figure 1: patient with swollen legs and ascites.

Significant antecedents included: menarche at 12 years old, and absence of menstrual periods for more than six months; asthma since she was two years old; measles at eight years old, occasional tonsillitis and flu; and allergy to dipyrone. The family history did not reveal significant data.

On physical examination were registered arterial hypertension (160/100mmHg) , severe swelling of the legs associated with increase in weight (from 63 to $110 \mathrm{~kg}$ ) and loss of muscular mass in the arms; lumbar lordosis and felon on the right halux. Her body was of regular aspect, the angle between arm and forearm was $180^{\circ}$, and costal-external angle was $90^{\circ}$.

Homeopathic approach was the one described by Pinto [7] and the following diagnoses were established: 1) Clinical: idiopathic nephrotic syndrome; 2) Dynamic clinical prognosis: severely lesional to incurable; 3) Biopathographic factors: pathological personal history; 4) Biotypologic: sulphuric; 5) Temperamental: atrabiliary; 6) Diathesic: sycosis and tuberculinism.

Symptoms selected and repertory correlations are described in Table 1. Repertory analysis was made with a repertorial homeopathic system [8], and results pointed out to Arsenicum album, Apis mellifica, Mercurius solubilis, Lachesis muta, Kali carbonicum, Calcarea ostrearum, Pulsatilla nigricans, Lycopodium clavatum, China officinalis, and Natrum muriaticum.

Table 1: Symptoms selected and repertory correlations

\begin{tabular}{|l|l|}
\hline Clinical symptoms & Repertory rubrics \\
\hline Anxiety for the future & Mind, anxiety future about \\
\hline Weeps easily & Mind, weeping tearful mood \\
\hline Jealousy & Mind, jealousy \\
\hline Desire for company & Mind, company desire alone aggravation \\
\hline Ailments from bad news & Mind, ailments bad news \\
\hline Sadness & Mind, sadness depression \\
\hline Swollen abdomen & Abdomen, hidropsy, ascites \\
\hline Swollen legs & Extremities, swelling hydropsical edematous \\
\hline Albuminuria & $\begin{array}{l}\text { Extremities, swelling lower limbs hydropsical } \\
\text { albuminúria in }\end{array}$ \\
\hline Felon & Extremities, felon panaritium \\
\hline Swelling in general & Generalities, swelling general in \\
\hline Anemia & Generalities, anemia \\
\hline
\end{tabular}


Table 2: Clinical progress and management

[AC: abdominal circunference (cm); BP: blood-pressure (mmHg)]

\begin{tabular}{|c|c|c|c|}
\hline Date & Clinical Evolution & Physical examination & Prescription \\
\hline 06/08/05 & $\begin{array}{l}\text { After visiting the psychologist, } \\
\text { she felt worst; had nightmares } \\
\text { involving doctors. Sleep and } \\
\text { bowels motions improved; urine } \\
\text { less foamy. More frightened and } \\
\text { discouraged. }\end{array}$ & $\begin{array}{l}\text { Swollen legs and face; } \\
\text { pale conjunctivae. } \\
\text { AC: } 130 ; \text { BP: } 120 / 90\end{array}$ & $\begin{array}{l}\text { Natrum sulphuricum } \\
(\text { Nat-s) } 6 \mathrm{cH} \text { at } \\
\text { morning }+ \text { Kidney } 6 \mathrm{cH} \\
\text { at night, once daily. }\end{array}$ \\
\hline 06/15/05 & $\begin{array}{l}\text { Can stretch her legs; still } \\
\text { irritated and frightened. }\end{array}$ & $\begin{array}{l}\text { Face no longer swollen; } \\
\text { pale conjunctivae; AC: } \\
123 ; \mathrm{BP}: 140 / 90\end{array}$ & The same. \\
\hline $06 / 22 / 05$ & $\begin{array}{l}\text { Anguished due to inflammation } \\
\text { and perspiration on right leg. } \\
\text { Has discontinued homeopathy } \\
\text { and took diuretics for two days } \\
\text { without improvement. }\end{array}$ & $\begin{array}{l}\text { Swollen legs and ascites; } \\
\text { pale conjunctivae; AC: } \\
\text { 123; BP: } 140 / 100\end{array}$ & $\begin{array}{l}\text { Tuberculinum of Koch } \\
(T K) 30 \mathrm{cH} \text { at morning } \\
+ \\
\text { Berberis vulgaris } \\
\text { (Berb-v) } 6 \mathrm{cH} \text { at night, } \\
\text { once daily. }\end{array}$ \\
\hline 07/06/05 & $\begin{array}{l}\text { Frequent and copious urination; } \\
\text { better appetite; thinner; } \\
\text { perspiration on right leg. } \\
\text { Brought laboratory exams. }\end{array}$ & $\begin{array}{l}\text { Swollen legs and ascites; } \\
\text { pale conjunctivae; } \\
\text { proteinuria: }+++; \\
\text { BP: } 140 / 90 \text {. }\end{array}$ & The same. \\
\hline 07/20/05 & $\begin{array}{l}\text { Feeling better; can use the } \\
\text { shower standing; abdomen is } \\
\text { softer; frequent and copious } \\
\text { urination; cramps in feet. }\end{array}$ & $\begin{array}{l}\text { Swollen legs and ascites; } \\
\text { pale conjunctivae; AC: } \\
\text { 130; BP: } 150 / 100\end{array}$ & Kidney $6 \mathrm{cH}$, once daily. \\
\hline 08/03/05 & Asthma crisis with fear of death. & $\begin{array}{l}\text { Swollen legs and ascites; } \\
\text { adenopathy on left side of } \\
\text { the neck. }\end{array}$ & $\begin{array}{l}\text { Adrenal } 6 \mathrm{cH}+\text { Kidney } \\
6 \mathrm{cH}+\text { Berb-v } 6 \mathrm{cH}+ \\
T K 30 \mathrm{cH}+\text { Iodium } 6 \mathrm{cH} \\
+, \text { once daily. }\end{array}$ \\
\hline 08/12/05 & $\begin{array}{l}\text { Discouraged; cannot watch TV } \\
\text { nor read magazines for religious } \\
\text { reasons. }\end{array}$ & $\begin{array}{l}\text { Swollen legs and ascites; } \\
\text { pale conjunctivae; BP: } \\
\text { 140/90; Weight: } 110 \mathrm{~kg}\end{array}$ & $\begin{array}{l}\text { Nat-s } 6 \mathrm{cH}+\text { Kidney } \\
6 \mathrm{cH} \text { twice a day. } \\
\text { Asked urine exam. }\end{array}$ \\
\hline $08 / 22 / 05$ & $\begin{array}{l}\text { Right leg inflamed and } \\
\text { perspiring; frightened but } \\
\text { hopeful. Did not make urine } \\
\text { exam. }\end{array}$ & $\begin{array}{l}\text { Vesicular eruption on } \\
\text { right leg (Figure } 2 \text { ); pale } \\
\text { conjunctivae; proteinuria: } \\
\text { + ; BP: } 140 / 90 ; \text { Weight: } \\
\text { 102kg. }\end{array}$ & $\begin{array}{l}\text { Nat-s } 6 \mathrm{ch}+\text { Kidney } \\
6 \mathrm{cH} \text { once daily. }\end{array}$ \\
\hline 09/16/05 & $\begin{array}{l}\text { Can lie on abdomen; stands up } \\
\text { quickly. Has been eating many } \\
\text { eggs and mayonnaise. }\end{array}$ & $\begin{array}{l}\text { Quick responses; pale } \\
\text { conjunctivae; lumbar } \\
\text { lordosis and legs swelling } \\
\text { diminished; BP: } 150 / 90\end{array}$ & $\begin{array}{l}\text { Nat-s } 6 \mathrm{cH}+\text { Cortisone } \\
6 \mathrm{cH} \text { at } 8 \text { a.m. and } 6 \\
\text { p.m. }\end{array}$ \\
\hline $10 / 14 / 05$ & $\begin{array}{l}\text { Anxiety about her health; hopes } \\
\text { to be well by Christmas. }\end{array}$ & $\begin{array}{l}\text { Scabs on right leg; full- } \\
\text { blooded lips and } \\
\text { conjunctivae; neck } \\
\text { adenopathy healed; } \\
\text { recovery of muscular }\end{array}$ & $\begin{array}{l}\text { Cortisone } 6 \mathrm{cH} \text { at } 8 \text { a.m. } \\
\text { and } 6 \text { p.m. }+ \text { Adrenal } \\
6 \mathrm{cH} \text { at } 8 \text { a.m. }+ \\
\text { Nat-s } 6 \mathrm{cH} \text { at } 6 \text { p.m. }+\end{array}$ \\
\hline
\end{tabular}




\begin{tabular}{|c|c|c|c|}
\hline & & $\begin{array}{l}\text { mass in arms; BP: } 140 / 90 ; \\
\text { Weight: } 103 \mathrm{~kg}\end{array}$ & $\begin{array}{l}\text { Apis } 6 \mathrm{cH} \text { at night. } \\
\text { Asked lab exams. }\end{array}$ \\
\hline $10 / 22 / 05$ & $\begin{array}{l}\text { Home call: intense headache and } \\
\text { fear of death. }\end{array}$ & $\begin{array}{l}\text { Very anxious; weight: } \\
98 \mathrm{~kg}\end{array}$ & $\begin{array}{l}\text { Magnesia sulphurica } \\
\text { (Mag-s) } 6 \mathrm{cH} \text { twice a } \\
\text { day. }\end{array}$ \\
\hline $10 / 24 / 05$ & $\begin{array}{l}\text { After headache, asthma crisis; } \\
\text { she attributed it to the exposure } \\
\text { to draft after showering. }\end{array}$ & $\begin{array}{l}\text { Dyspnea and wheezing; } \\
\text { Proteinuria: }++\end{array}$ & $\begin{array}{l}\text { Arsenicum album (Ars- } \\
\text { a) } 6 \mathrm{cH} \text {, nebulization } 3 \\
\text { times daily }\end{array}$ \\
\hline $11 / 09 / 05$ & $\begin{array}{l}\text { Frightened due to headache } \\
\text { after a row with her brother. }\end{array}$ & BP: 140/100; weight: $92 \mathrm{~kg}$ & $\begin{array}{l}\text { Mag-s } 6 \mathrm{cH} \text {, twice a } \\
\text { day. }\end{array}$ \\
\hline $11 / 14 / 05$ & $\begin{array}{l}\text { After headache, severe } \\
\text { abdominal pain and diarrhea, } \\
\text { asked her parents to hold her } \\
\text { belly. }\end{array}$ & BP: 110/70; weight: $90 \mathrm{~kg}$ & Apis $6 \mathrm{cH}$, once daily. \\
\hline $12 / 7 / 05$ & $\begin{array}{l}\text { Physically better but } \\
\text { psychologically unwell; very } \\
\text { needy of her parents; } \\
\text { complaining and waiting for } \\
\text { Christmas. }\end{array}$ & BP: $120 / 80$; weight: $84 \mathrm{~kg}$ & The same. \\
\hline $12 / 28 / 05$ & $\begin{array}{l}\text { Well at Christmas, but angry } \\
\text { about the previous weekend. }\end{array}$ & BP: $120 / 80$; weight: $74 \mathrm{~kg}$ & The same. \\
\hline 01/11/06 & $\begin{array}{l}\text { Well at New Year's party; urine } \\
\text { is still foamy. }\end{array}$ & $\begin{array}{l}\text { Legs are thin and } \\
\text { wrinkled; BP: } 140 / 80 \text {; } \\
\text { weight: } 65 \mathrm{~kg}\end{array}$ & $\begin{array}{l}\text { Apis } 30 \mathrm{cH} \text { once daily. } \\
\text { Lab exams requested. }\end{array}$ \\
\hline $01 / 26 / 06$ & $\begin{array}{l}\text { Angry and weak; headache } \\
\text { extending to face and eyes, } \\
\text { worse on the right side. Has not } \\
\text { made lab exams requested. }\end{array}$ & BP: 120/70; weight: $59 \mathrm{~kg}$ & The same. \\
\hline $02 / 15 / 06$ & $\begin{array}{l}\text { Toothache extending to the right } \\
\text { side of the body and diplopia; } \\
\text { frightened. }\end{array}$ & $\begin{array}{l}3^{\text {rd }} \text { molar inflamed, facial } \\
\text { sensitiveness, right } \\
\text { horizontal strabismus } \\
\text { (Figure 3). Lab } \\
\text { tests:hypoalbuminemia: } \\
1.2 \mathrm{~g} / \mathrm{dL} \text {; proteinuria: } \\
\text { +++; BP: } 140 / 80 \text {; weight: } \\
58 \mathrm{~kg}\end{array}$ & $\begin{array}{l}\text { Arnica } 6 \mathrm{cH}+\text { Silicia } \\
6 \mathrm{cH}+\text { Calc-p } 6 \mathrm{cH}+ \\
\text { Calc-f } 6 \mathrm{cH} \text {, once daily. }\end{array}$ \\
\hline $\begin{array}{l}03 / 01 / 06 \\
03 / 15 / 06\end{array}$ & $\begin{array}{l}\text { Feeling well despite the } \\
\text { toothache and diplopia. }\end{array}$ & BP: $140 / 90$; weight: $57 \mathrm{~kg}$ & $\begin{array}{l}\text { The same }+ \text { Adrenal } \\
6 \mathrm{cH} \text {. Urine exam } \\
\text { requested. }\end{array}$ \\
\hline $04 / 15 / 06$ & $\begin{array}{l}\text { At her birthday party overate } \\
\text { until feeling ill. Urine is still } \\
\text { foamy. }\end{array}$ & $\begin{array}{l}\text { Urine exam: proteinuria } \\
(++) \text {. Weight: } 53 \mathrm{~kg}\end{array}$ & $\begin{array}{l}\text { Apis } 6 \mathrm{cH}+ \\
\text { Nat-s } 6 \mathrm{cH} \text {, } \\
\text { Once daily. }\end{array}$ \\
\hline 05/17/06 & $\begin{array}{l}\text { "She's again who she was", said } \\
\text { her mother. Very happy, lust for } \\
\text { life. Menstruation came back. }\end{array}$ & Weight: $58 \mathrm{~kg}$ & Without medication. \\
\hline 07/12/06 & Toothache. & & $\begin{array}{l}\text { Magnesia carbonica } \\
6 \mathrm{cH}+\text { Arnica } 6 \mathrm{cH}+ \\
\text { Silicia } 6 \mathrm{cH}+\text { Calc-p }\end{array}$ \\
\hline
\end{tabular}




\begin{tabular}{|l|l|l|l|}
\hline & & & $\begin{array}{l}6 \mathrm{cH}+\text { Calc-f 6cH, } \\
\text { once daily. }\end{array}$ \\
\hline $08 / 09 / 06$ & $\begin{array}{l}\text { Menstruated in July and } \\
\text { August, with swelling and } \\
\text { unwell. }\end{array}$ & & Apis 6cH once daily. \\
\hline $10 / 18 / 06$ & No clinical complaints (Figure 4). & BP: $120 / 80 ;$ weight: $65 \mathrm{~kg}$ & Discharge. \\
\hline
\end{tabular}

Based on the diagnoses established, it was prescribed Apis mellifica $6 \mathrm{cH}$ and Berberis vulgaris $6 \mathrm{cH}$ once daily. Clinical progress and management are described in Table 2. All medicines were taken in the dosage of five tablets.

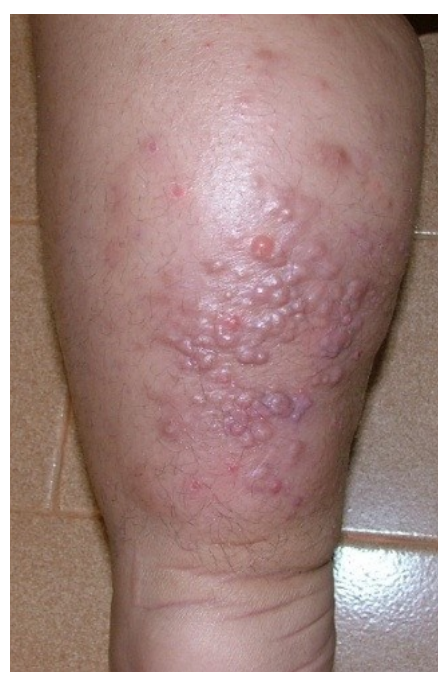

Figure 2: patient with vesicular eruption on right leg.

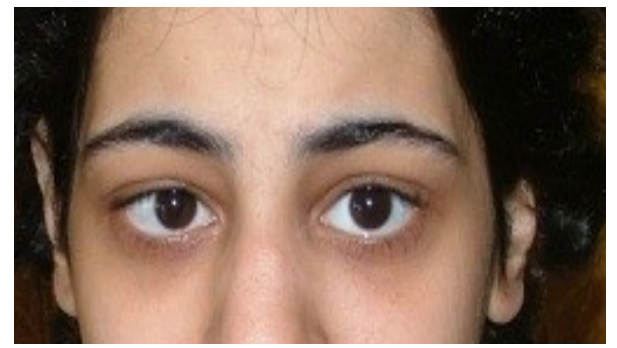

Figure 3: patient with right horizontal strabismus.

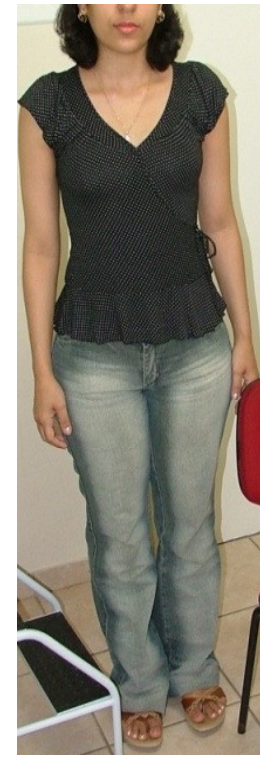

Figure 4: patient after treatment.

\section{Discussion}

The patient had a clinical diagnosis of idiopathic nephrotic syndrome based on the laboratory findings of anemia and albuminuria and focal segmental glomerulosclerosis, which is the most common form of glomerulopathy causing nephrotic syndrome in adults [1,2], and determines a poor prognosis [9]

Six diagnoses were made to build the clinical homeopathic picture of the patient and to determine the adequate medicines to be prescribed, according to clinical protocol employed [7].

Regarding biopathographic aspects, the patient had a history of chronic dynamic diseases, possibly sycosis (measles, tonsillitis and flu), tuberculinism (asthma), and psora (allergies) [7, 10, 11].

Nephrotic syndrome was classified as sycosis and was prescribed Apis mellifica $6 \mathrm{cH}$ and Berberis vulgaris $6 \mathrm{cH}$ to promote kidney stimulation. This procedure resulted in clinical aggravation, according to first or second Kent`s prognosis [12], 
recorded by increasing the swelling of the face and extremities, and worsening of the psyche.

Therefore, the diathesic medicine was interrupted and administered the constitutional (Natrum sulphuricum $6 \mathrm{cH}$ ) and the biotherapic (Kidney $6 \mathrm{cH}$, Adrenal $6 \mathrm{cH}$ and Cortisone $6 \mathrm{cH}$ ) medicines at different times. This procedure can be performed when there are serious organ dysfunctions [7].

As the patient did not improve, and based on her personal history and the occurrence of asthma and adenopathy, the presence of tuberculinism was considered. . In these cases, when dissimilar diseases occur [13], it is necessary to treat the dominant chronic disease first [7, 10]. Thus, Tuberculinum of Koch $30 \mathrm{cH}$, Iodium $6 \mathrm{cH}$ and Arsenicum album $6 \mathrm{cH}$ were prescribed at different times. After this, the clinical improvement started to be shown by weight loss, full-blooded lips and conjunctivae, and recovery of muscular mass in arms.

Despite the clinical evolution, swollen legs, ascites and albuminuria remained. Therefore, was prescribed Apis mellifica $(6 \mathrm{cH}$ and $30 \mathrm{cH})$ to finish the sycosis treatment. Consequently, the resumption of growth of the mandibular third molar tooth, the recovery of body weight and muscular mass in arms, and the return of the menstrual flow were observed, characterizing the recovery of the sanguine temperament which corresponds to the biological age of the patient [7].

The growth of the mandibular third molar tooth caused an inflammatory process adjacent to the trigeminal nerve root that resulted in toothache, headache and strabismus. These clinical manifestations were treated with circumstantial medicines [14].

Remission or relapse of nephrotic syndrome can happens after corticosteroids and cytotoxic drugs treatment [15]. Nevertheless, this patient showed the most common change renal (membranous glomerulonephritis) after two spontaneous remission and no responded to conventional treatment. In spite of her poor prognosis the clinical remission occurred after judicious homeopathic treatment and there was no relapse during the 28-month follow-up. Similarly, in a case reported about the homeopathic treatment of vaginal leiomyoma in a dog, considered clinically incurable, in which the same clinical protocol was used, the clinical remission was also demonstrated [16]. The fact that this protocol has been described in veterinary medicine means that it is an objective method whose results were destitute of placebo effect. This makes it reliable to be used in humans patients.

\section{Conclusions}

Nephrotic syndrome is a chronic dynamic disease which requires specific treatment to the diathesis sycosis.

The satisfactory outcome in this case shows that the judicious homeopathic therapeutic may be a valuable resource in the treatment of nephrotic syndrome.

\section{References}

[1] Harrison TR. Medicina Interna. 15 $5^{\text {th }}$ ed, Rio de Janeiro (Brazil): Mc Graw Hill; 2002.

[2] Agraharkar M, Gala G, Gangakhedkar AK. Nephrotic syndrome. emedicine [online]. $2007 \mathrm{Feb}$ 1 [cited $2007 \mathrm{Feb} 10$ ]. [about 20 p]. Available from: http://emedicine.medscape.com/article/244631overview.

[3] Schieppati A, Perna A, Zamora J, Giuliano GA, Braun N, Remuzzi G. Immunosuppressive treatment for idiopathic membranous nephropathy in adults with nephrotic syndrome. Cochrane Database of Systematic Reviews [online]. 2004; Issue 4. [Art. No.: CD004293]. [DOI: 10.1002/14651858.CD004293.pub2]. Available from: http://www.cochrane.org/reviews/en/ab004293.html

[4] Schwarz A. New aspects of the treatment of nephrotic syndrome. J Am Soc Nephrol. 2001; 12: S44-S47.

[5] Jonas WB, Anderson RL, Crawford CC, et al. A systematic review of the quality of homeopathic clinical trials. BMC Compl Alternative Med [online]. 2001; 1. [DOI:10.1186/1472-6882-1-12]. Available from: www.biomedcentral.com/1472$\underline{682 / 1 / 12}$.

[6] Ernst E, Pittler MH. Efficacy of homeopathic arnica: a systematic review of placebo-controlled clinical trials. Arch Surg [online]. 1998 [cited 2007 Aug 22]; 133. [about 5 p]. Available from:

http://archsurg.amaassn.org/cgi/content/full/133/11/1187.

[7] Pinto LF. Homeopathic veterinary clinical protocol. In: Bonamin LV, editor. Signals and images II: contributions and contradictions about high dilution research. New York (United States): Springer; 2008.

[8] Favilla JP. SIHORE: Sistema de homeopatia repertorial Versão 2004 [CD-Rom]. São Paulo; SIHORE; 2004.

[9] Mendoza SA, Tune BM. Management of the difficult nephrotic patient. Pediatr Clin North Am. 1995; 42: 1459-1468.

[10] Carillo Junior R. The law of similarity, dissimilarity and physiology - The principles for the comprehension of chronic diseases and their homeopathic treatment. Braz Homeopathic J. 2002; 8(2): 92-102. 
[11] Kossak-Romanach A. Homeopatia em 1000 conceitos. $3^{\text {rd }}$ ed, São Paulo (Brazil): Elcid; 2003.

[12] Kent JT. 1849-1916. Lectures of Homoeopathic Philosophy. New Delhi (India): B Jain; 1987.

[13] Hahnemann S.1755-1843. Organon da arte de curar. 2nd ed, Ribeirão Preto (Brazil): Museu de Homeopatia Abrahão Brickmann; 1995.

[14] Vannier L, Poirier J. Tratado de Matéria Médica Homeopática. 9 $9^{\text {nd }}$ ed, São Paulo (Brazil): Andrei; 1987.
[15] Nolasco F, Cameron JS, Heywood EF, Hicks J, Ogg C, Willians DG. Adult-onset minimal change nephrotic syndrome: A long-term follow-up. Kidney Int. 1986; 29: 1215-1223.

[16] Ferreira MIC, Pinto LF. Homeopathic treatment of vaginal leiomyoma in a dog: case report. Int J High Dilution Res [online]. 2008 [cited 2007 Feb 10]; 7(24):152-158. Available from: http://www.feg.unesp.br/ ojs/index.php/ijhdr/articl e/view/304/358.

(cc)) BY-Nc-ND Licensed to GIRI

Support: authors declare that this study received no funding Conflict of interest: authors declare there is no conflict of interest Received: 27 Aug 2008; Revised 12 Feb 2009; Published: 31 Mar 2009

Correspondence author: Luiz Figueira Pinto, luizfigueira@ufrrj.br

How to cite this article: Pinto LF. A case of idiopathic nephrotic syndrome treated with the homeopathic therapeutic. Int $J$ High Dilution Res [online]. 2009 [cited YYYY Mmm dd]; 8(26):26-32. Available from:

http://www.feg.unesp.br/ ojs/index.php/ijhdr/article/view/302/382 